\title{
Effectiveness of the Maguerez Arch in nursing teaching on vesical catheterism: an almost experimental study
}

\author{
Efetividade do Arco de Maguerez no ensino de enfermagem \\ sobre cateterismo vesical: estudo quase-experimental \\ Eficacia del Arco de Maguerez en la enseñanza de enfermería \\ en cateterismo vesical: un estudio casi-experimental
}

\author{
Jonatan Deyson do Nascimento de Sousa ${ }^{a}$ \\ Cristina da Silva Fernandes ${ }^{\mathrm{a}}$ \\ Maria Aline Moreira Ximenes ${ }^{b}$ \\ Joselany Áfio Caetano ${ }^{b}$ \\ Nelson Miguel Galindo Netoc \\ Lívia Moreira Barros ${ }^{\mathrm{d}}$
}

\section{How to cite this article:}

Sousa JDN, Fernandes CS, Ximenes MAM, Caetano JA, Galindo Neto NM, Barros LM. Effectiveness of the Maguerez Arch in nursing teaching on vesical catheterism: an almost experimental study. Rev Gaúcha Enferm. 2021;42:e20200105 doi: https://doi.org/10.1590/19831447.2021.20200105
Universidade Estadual Vale do Acaraú (UVA). Sobral, Ceará, Brasil

b Universidade Federal do Ceará (UFCE) . Fortaleza, Ceará, Brasil.

Instituto Federal de Educação, Ciência e Tecnologia de Pernambuco (IFPE). Pesqueira, Pernambuco, Brasil.

d Universidade da Integração Internacional da Lusofonia Afro-Brasileira (UNILAB). Redenção, Ceará, Brasil.

\section{ABSTRACT}

Objective: To evaluate the effectiveness of the Arco de Maguerez in teaching nursing students about the Bladder Catheter.

Method: Quasi-experimental study conducted at a public university in northeastern Brazil, with 29 students, in a single group, in the period of october 2018. Data were collected before and after using the Arco de Maguerez in educational intervention, using validated instruments, referring to knowledge and practice. IBM SPSS Statistics software version 24 was used for statistical analysis. The level of significance was set at $5 \%$ and the $95 \%$ confidence interval. Data analysis was performed using the McNemar and Mann-Whitney test. Results: The median of correct answers for knowledge was 7, in the pre-test, and 9 in the post-test ( $p>0.001$ ). Regarding practice, in the pre-test the median of correct answers was 28 and, in the post-test, it went to $36, p>0.001$. The academics explained that the AM technology based on the problematization of a fictitious clinical case made learning about Bladder Catheterization Delay clear and feasible. Conclusion: The Arco de Maguerez was effective in improving the knowledge and skill of nursing students regarding the Bladder Catheter.

Keywords: Nursing. Urinary catheterization. Students, nursing. Teaching materials. Educational technology.

\section{RESUMO}

Objetivo: Avaliar a efetividade do Arco de Maguerez no ensino de acadêmicos de enfermagem sobre o Cateter Vesical de Demora. Método: Estudo quase-experimental realizado em universidade pública no nordeste brasileiro, com 29 discentes, em grupo único, no período de outubro de 2018. Os dados foram coletados antes e depois da utilização do Arco de Maguerez em intervenção educativa, a partir de instrumentos validados, referentes ao conhecimento e prática. Foi utilizado o software IBM SPSS Statistics versão 24 para análise estatística. 0 nível de significância adotado foi de 5\% e o intervalo de confiança de 95\%. A análise dos dados ocorreu a partir do teste de McNemar e Mann-Whitney.

Resultados: A mediana de acertos do conhecimento foi de 7, no pré-teste, e 9 no pós-teste ( $p>0,001)$. Em relação à prática, no pré-teste a mediana de acertos foi de 28 e, no pós-teste, passou para 36, p>0,001. Os acadêmicos expuseram que a tecnologia do AM baseada na problematização de caso clínico fictício tornou o aprendizado sobre Cateterismo Vesical de Demora claro e factível.

Conclusão: 0 Arco de Maguerez foi efetivo para melhorar o conhecimento e a habilidade dos acadêmicos de enfermagem, referentes ao Cateterismo Vesical de Demora.

Palavras-chave: Enfermagem. Cateterismo urinário. Estudantes de enfermagem. Materiais de ensino. Tecnologia educacional.

\section{RESUMEN}

Objetivo: Evaluar la efectividad del Arco de Maguerez para enseñar a los estudiantes de enfermería sobre el cateter vesical.

Método: Estudio cuasiexperimental realizado en una universidad pública del noreste de Brasil, con 29 estudiantes, en un solo grupo, en el período de octubre de 2018. Los datos se recopilaron antes y después de usar el Arco de Maguerez en la intervención educativa, utilizando instrumentos validados, en referencia al conocimiento y la práctica. Para el análisis estadístico se utilizó el software IBM SPSS Statistics versión 24. El nivel de significancia se estableció en el 5\% y el intervalo de confianza del $95 \%$. El análisis de los datos se realizó mediante la prueba de McNemar y Mann-Whitney.

Resultados: La mediana de las respuestas correctas para el conocimiento fue 7, en la prueba previa y 9 en la prueba posterior ( $p>$ 0.001). En cuanto a la práctica, en la prueba previa la mediana de las respuestas correctas fue 28 y, en la prueba posterior, fue a 36, $p>0.001$. Los académicos explicaron que la tecnología AM basada en la problematización de un caso clínico ficticio hizo que el aprendizaje sobre el Retardo de Cateterización de la Vejiga fuera claro y factible.

Conclusión: El Arco de Maguerez fue eficaz para mejorar el conocimiento y la habilidad de los estudiantes de enfermería con respecto al cateter vesical.

Palabras clave: Enfermería. Cateterismo urinario. Estudiantes de enfermeria. Materiales de enseñanza. Tecnología educacional. 


\section{口INTRODUCTION}

The indwelling urinary catheter (IUC) is one of the most commonly used invasive devices in health care. It is indicated for patients with urinary incontinence or retention and it is used for measuring diuresis, collecting urine samples, and for irrigating or administering medication into the bladder ${ }^{(1)}$.

The rate of IUC usage in critical hospitalized patients in France is $12 \%{ }^{(2)}$. In Brazil, studies indicate that, in critical care such as intensive care, the catheter is used in more than $90 \%$ of patients, of which $13 \%$ remain with the device for more than 30 days $^{(3)}$.

The correct insertion of the IUC is relevant since faults can cause contamination of the bladder by microorganisms ${ }^{(4)}$. Thus, nurses who insert and handle IUCs must know the indications of use, risks, and benefits, and they must be skilled in the procedure ${ }^{(5)}$.

Therefore, bladder catheterization training during undergraduate studies is critical and directly influences the quality of professional care and safe patient care. In this regard, Brazilian studies show satisfactory theoretical knowledge in $62.1 \%$ of nursing students ${ }^{(6)}$ and correct insertion of IUC in 59.3\% of students ${ }^{(7)}$, which stresses the importance of investments in training for this procedure during undergraduate studies to improve these indicators.

The teaching that precedes the actual practice of IUC increases the knowledge and confidence of students ${ }^{(8)}$, however, the chosen learning strategy should focus on scientific results to support IUC training with evidence-based practice. In higher education, professors are encouraged to rethink their practice and replace traditional teaching methods with more specific methodologies, especially due to the characteristics of the adult student ${ }^{(9)}$. One of the most effective strategies for health education and a possible target of research is problem-based learning through the arc of Maguerez (AM) method.

This active methodology integrates the contextualization of the reality to be discussed and the creation of a solution plan from the collective practice and joint decision-making among the students, culminating in the construction of feasible strategies for solving or improving the problem-situation ${ }^{(10)}$. In this regard, the AM is configured as a problem-based learning method since the contents constructed by students must be adapted to their previous cognitive structure in order to discover relationships, laws, or concepts necessary for their learning ${ }^{(11)}$.

In terms of ensuring student autonomy and co-accountability in the learning process ${ }^{(10)}$, the AM is considered a strategy that allows students to reflect through the observation of reality, build the knowledge they need to solve these problems, and, thus, transform the teaching-learning process on IUC.

The extensive use of IUC supports the relevance of knowledge and practice on the part of nursing students regarding this procedure. Furthermore, problem-based learning with AM has proved effective for teaching various topics in nursing, which further supports the need to study the effectiveness of AM and the practice of nursing students regarding IUC.

Therefore, the research question was, "is the Maguerez arc effective in teaching nursing students about the indwelling urinary catheter?". By the end of study follow-up, it is believed that the theory and practice knowledge on IUC of the students who participated in the educational intervention with the active learning method based on AM should have improved.

Therefore, the results of this study may contribute to the decision-making of professionals involved in nursing training and IUC training. This study aimed to evaluate the effectiveness of the Maguerez arc in teaching nursing students about indwelling urinary catheter (IUC).

\section{METHOD}

This is a quasi-experimental study with a before-and-after design, in which all groups are exposed to the intervention. Thus, the individual is his or her own control. It was conducted at a public higher education institution (IES) in the state of Ceará, Brazil, in October 2018, during the adult life academic module taught in the fourth semester of the undergraduate program, with 160 classroom hours. In this module, students can learn the IUC technique for the first time in the nursing course.

The target population was students enrolled in this module, totaling 29 students. The inclusion criterion was students regularly enrolled in the course and the exclusion criterion was students who had not attended the educational intervention or who had not participated in all stages of the intervention. The final sample consisted of 29 students. Sampling was intentional and non-probabilistic and there was no sample calculation since the entire target population participated in the study.

Data were collected in the three following stages: I - theory and practice pre-tests; II - learning based on the Maguerez arc, with problem-based learning; III - theory and practice post-tests, as shown in Figure 1.

All stages took place in a private room at the university, except for the practice tests, which took place in the skills 
laboratory, according to student availability and outside classroom hours so as not to interrupt the students' attendance in curricular activities. Application of the instruments did not influence student evaluations in the module since this educational intervention was considered an extra moment of the module and student participation was not mandatory.

At the first session, the objective of the teaching strategy was presented and informed consent was obtained. Subsequently, the theory and practice tests were applied. For the theory evaluation, all students sat at desks in rows and were asked to answer the test questions at the same time. For this stage, a knowledge instrument built and validated by Balduino ${ }^{(12)}$ was used, containing 12 closed-end, multiple-choice questions on indwelling urinary catheterization with five alternatives each, of which only one was correct.

Immediately after the theory pre-test, the students underwent a practice evaluation consisting of a structured checklist script also constructed and validated by Balduino ${ }^{(12)}$. The checklist contained 36 items divided into the following two blocks: initial observations, regarding the steps that precede insertion of indwelling urinary catheter (with eight steps) and insertion procedure of indwelling urinary catheter (with 31 steps), corresponding to the step-by-step process to correctly perform the procedure.
For the practice test, all the students were asked to go individually to the nursing laboratory of the institution. Upon entering the laboratory, the participant was asked to insert the indwelling urinary catheter into the dummy. Moreover, the student had to choose the necessary materials arranged near the patient's bed before initiating passage of the probe. The procedure performed by the students was observed by three professors, with experience in teaching the procedure, who separately completed the checklist mentioned above.

One day after the pre-test, the students participated in the educational intervention based on the Maguerez arc method, in which a clinical case from a contextualized story about urinary dysfunction was presented to elicit possible conducts to solve the problems described, regarding insertion of IUC. The arc of Charles Maguerez for problem-based learning, which consists of five stages (observation of reality and definition of a problem, key points, theorization, solution hypotheses, and application to reality) ${ }^{(10)}$, was applied for IUC, as shown in Chart 1.

The class was informed of the stages of the Maguerez arc, after which it was divided into six groups using a draw and each group sat at desks in different corners of the room to read the clinical case.

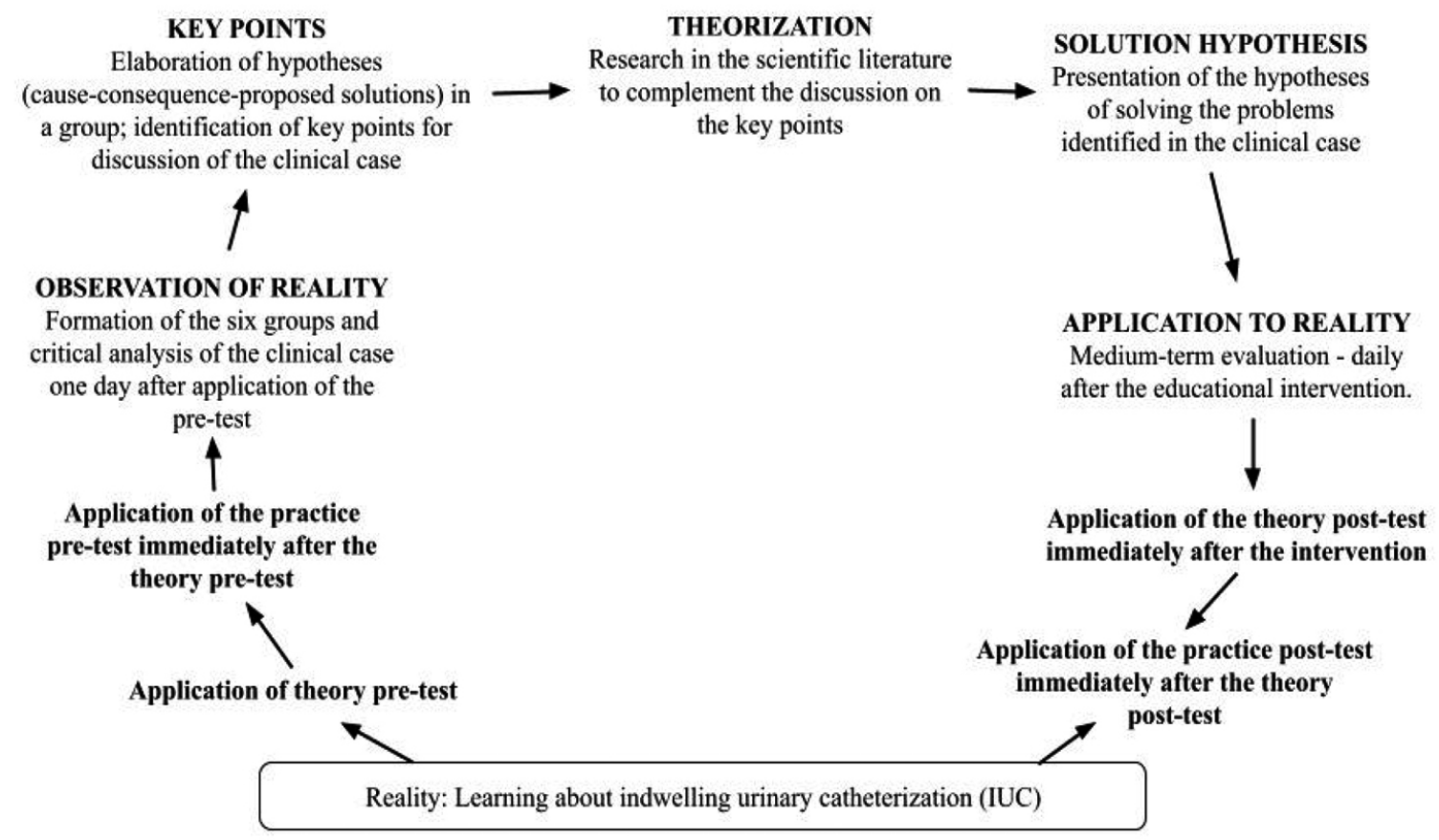

Figure 1 - Stages of the educational intervention based on the arc of Maguerez framework. Sobral, CE, 2019 Source: Authors, 2020 . 
The initial stage, the observation of reality, enabled the students to reflect critically on the clinical history of the case. Thereafter, each group was given instructions and asked to survey the key points based on their thoughts regarding the problems present in the clinical case.

In the following stage, theorization, the students searched for additional information on the identified problem in the scientific literature, from the scientific articles that were made available to them. Then, the students were informed to continue searching for information and list hypotheses of the solution. In the application to reality stage, the groups were shown to the skills laboratory, where they individually performed the IUC procedure, followed by a talk session, where they presented the knowledge obtained and described the expected results based on the interventions that were previously suggested.

The third and last stage of the study, consisting of the post-tests, occurred shortly after the students completed the intervention with the Maguerez arc. It is noteworthy that the theory and practice post-tests occurred in a similar way, in the same places and with the same instruments as in the pre-tests.

The data were entered into Excel spreadsheets and processed using SPSS (Statistical Package for the Social Sciences) software, version 24, for statistical analysis. Categorical variables were analyzed from absolute and percentage frequencies. Non-adherence to the normality of continuous data was confirmed with the Kolmogorov-Smirnov test.

Correct general knowledge and skill answers were analyzed using the median with respective interquartile ranges $25 \%$ and $75 \%$ and submitted to the Mann-Whitney test to compare the correct answer medians. Data of the theory and practice evaluations, per item, were submitted to the McNemar test to verify the change in status between the pre- and post-tests. The significance level adopted in all tests was $5 \%$ and the confidence interval was $95 \%$.

The study was approved by the Research Ethics Committee of Vale do Acaraú State University (opinion:2.806.678) on August 08, 2018, after compliance with resolution \#466/2012 of the National Health Council.

\begin{tabular}{|c|c|c|}
\hline Stage & Objectives & Activities performed \\
\hline $\begin{array}{l}\text { Observation } \\
\text { of reality and } \\
\text { definition of } \\
\text { a problem }\end{array}$ & $\begin{array}{l}\text { Approaching the theme and } \\
\text { identifying problems. }\end{array}$ & $\begin{array}{l}\text { - Contact of students with reality similar to clinical practice, from } \\
\text { clinical case. } \\
\text { - Clinical, critical, and holistic observation of the case in question. } \\
\text { - Identifying the problem about diuresis. }\end{array}$ \\
\hline Key points & $\begin{array}{l}\text { Reflecting on the identified } \\
\text { problems and defining the } \\
\text { key points for } \\
\text { research. }\end{array}$ & $\begin{array}{l}\text { - Group discussion on the case. } \\
\text { - Identifying the main problems related to urinary changes. } \\
\text { - Recognizing care needs. }\end{array}$ \\
\hline Theorization & $\begin{array}{l}\text { Investigating each key point, } \\
\text { finding reliable information, } \\
\text { and analyzing it to solve } \\
\text { the problems. }\end{array}$ & $\begin{array}{l}\text { - Contact of students with the scientific literature, from available } \\
\text { scientific articles. } \\
\text { - Discussion on the topic among students. }\end{array}$ \\
\hline $\begin{array}{l}\text { Solution } \\
\text { hypotheses }\end{array}$ & $\begin{array}{l}\text { Suggesting interventions to } \\
\text { solve or reduce the damage } \\
\text { of the problems for patients. }\end{array}$ & $\begin{array}{l}\text { - Suggesting nursing interventions. } \\
\text { - Reflecting on health promotion actions and active } \\
\text { participation of the patient in care. }\end{array}$ \\
\hline $\begin{array}{l}\text { Application } \\
\text { to reality }\end{array}$ & $\begin{array}{l}\text { Expected return based on } \\
\text { practice applied to reality. }\end{array}$ & $\begin{array}{l}\text { - Practice and record of indwelling urinary catheterization. } \\
\text { - Presentation of the expected results in practice based on the } \\
\text { proposed nursing interventions. } \\
\text { - Socialization of constructed knowledge, in talk session. }\end{array}$ \\
\hline
\end{tabular}

Chart 1 - Synthesis of the Maguerez arc used to teach indwelling urinary catheterization. Sobral, CE, Brazil, 2019 Source: Authors, 2020. 


\section{RESULTS}

Most of the 29 students evaluated were female (75\%), with a minimum age of 19 years and a maximum of 27 years, and a mean age of $20.10( \pm 1.67)$ years. Regarding contact with the subject, $78.5 \%$ confirmed having had previous contact with the subject of urinary disorders in the classes of physiology applied to nursing.

Figure 2 shows the results of the stages of the Maguerez arc developed as a reference for the applied educational intervention.

In the stage of reality observation stage, after critical analysis of the proposed situation, the six groups of students were able to identify the problem of the clinical case based on the nursing interventions required for the presented urinary disorder. They subsequently listed key points, such as clinical signs and symptoms of the fictitious patient and their correlation with nursing diagnoses, and identified the necessary interventions to achieve the expected results. They also determined whether there was a clinical indication for the choice of IUC to relieve water retention, care required before and after the procedure, and the correct guidelines for patients.

In the theorization stage, they associated the clinical case with the scientific literature and substantiated its key points in the research, which promoted evidence-based practice from the systematization of nursing care. During the solution hypothesis, the students presented care such as anamnesis and physical examination to learn about the patient's clinical history, guidelines on the procedure, and nursing record as fundamental care before and after IUC.

Thereafter, all the students participated in a talk session to present their synthesis of discussions and solutions for the clinical case proposed in the Maguerez arc. Finally, after simulating insertion of the IUC in a dummy, the students reported being satisfied with the educational strategy since it aroused their interest in learning about and solving the clinical case and showed them the relationship between theory and practice associated with bladder catheterization.

Regarding knowledge, the pre-test resulted in a median of 7 correct scores $(\mathrm{IQ}=5-8)$, while in the post-test, the median was $9(\mathrm{IQ}=8-10)$. Therefore, significance was observed in the increased mean of correct theory scores ( $p>0.001)$. Table 1 shows the correct score rates of each question in the applied questionnaire.

Regarding observation of the practice, in the pre-test, the median was 28 correct scores $(\mathrm{IQ}=18-31)$ and in the post-test, the median was $36(\mathrm{IQ}=32-38)$, indicating a significance in the increased mean of the correct practice scores ( $p>0.001$ ). To facilitate understanding of the data, the skills of nursing students were subdivided in relation to material preparation, procedure execution, and post-IUC care.

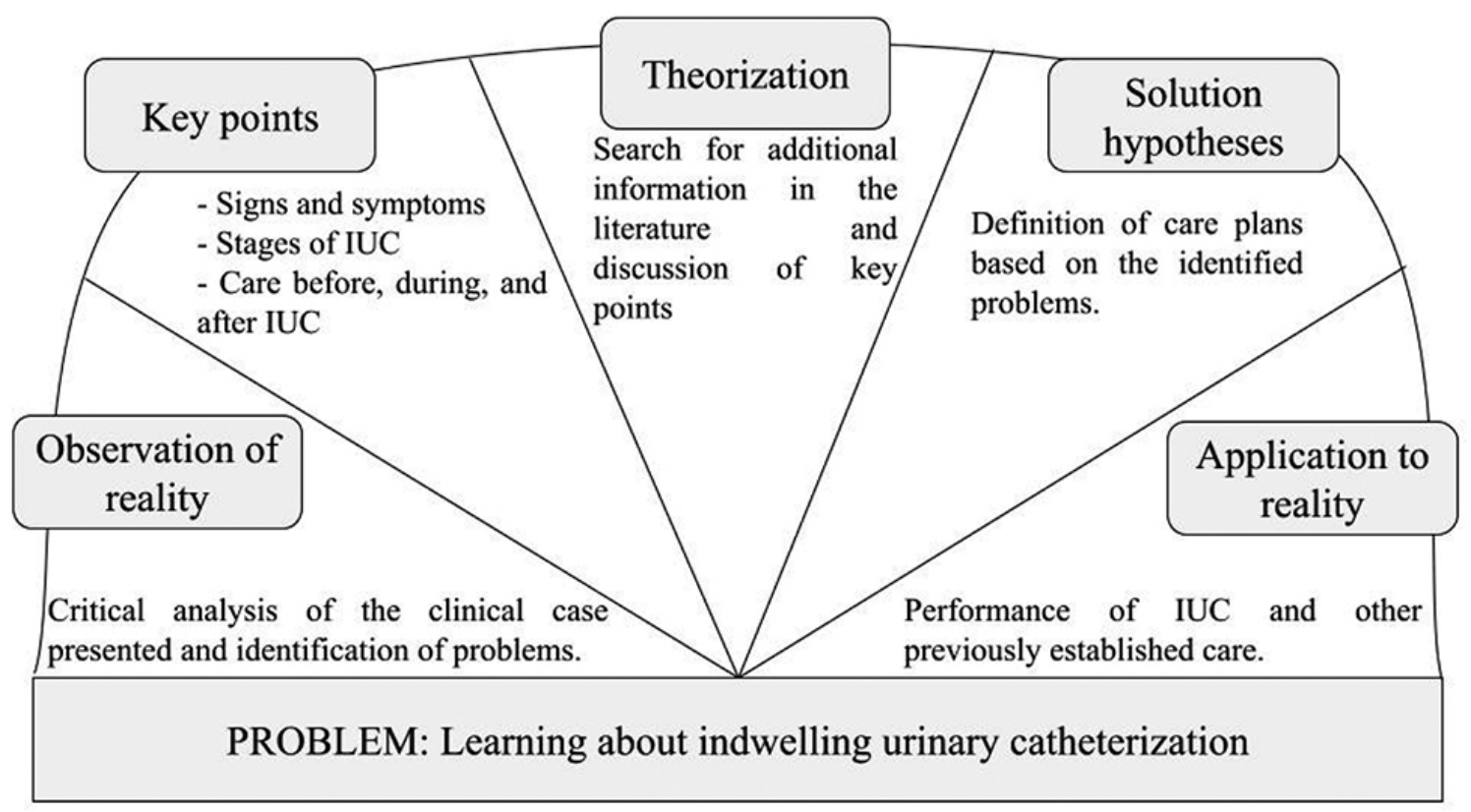

Figure 2 - Stages for use of the Maguerez arc as an educational intervention.

Sobral, $, E, 2019$

Source: Authors, 2020 
Regarding preparation of the material, an improvement in the student's practice was observed regarding checking the prescription, performing hand sanitization, and preparing the necessary material before starting bladder catheterization (Table 2).
Regarding observation of procedure execution for the 27 evaluated items, an increase in the correct scores was observed for all students, with statistical significance in 17 and unanimity of correct scores in 7 (Table 3).

Table 1 - Correct scores in each item of the questionnaire used to evaluate the theoretical knowledge of students regarding indwelling urinary catheterization, Sobral, CE, Brazil, 2019

\begin{tabular}{|c|c|c|c|}
\hline Questions & $\begin{array}{l}\text { Pre-test } \\
\text { n(\%) }\end{array}$ & $\begin{array}{c}\text { Post-test } \\
\mathbf{n}(\%)\end{array}$ & p-value* \\
\hline 1. Selection of materials required for IUC & $24(82.8 \%)$ & $26(89.7 \%)$ & 0.500 \\
\hline 2. Preparation of the environment and materials before starting IUC & $18(62.1 \%)$ & $19(65 \%)$ & 1.000 \\
\hline 3. Correct sequence of the IUC technique & $6(20.7 \%)$ & $17(58.6 \%)$ & 0.001 \\
\hline 4. First step to avoiding UTI & $25(86.2 \%)$ & $24(82.8 \%)$ & 1.000 \\
\hline 5. Patient preparation for IUC & $22(75.9 \%)$ & 23(79.3\%) & 1.000 \\
\hline 6. Criteria for switching probes & $1(3.4 \%)$ & $6(20.7 \%)$ & 0.125 \\
\hline 7. Care of materials for catheterization & $18(62 \%)$ & $27(93.1 \%)$ & 0.120 \\
\hline 8. Correct sequence of penis cleansing & $13(44.8 \%)$ & $18(62.1 \%)$ & 0.180 \\
\hline 9. Material handling during IUC & $8(27.6 \%)$ & 27(93.1\%) & $<0.001$ \\
\hline 10. Positioning of the penis during catheter insertion & $7(24.1 \%)$ & $27(93.1 \%)$ & $<0.001$ \\
\hline 11. Care in completion/fixation of the IUC & $7(24.1 \%)$ & $21(72.4 \%)$ & 0.004 \\
\hline 12. Care after passage of IUC & $28(96.6 \%)$ & 27(93.1\%) & 1.000 \\
\hline
\end{tabular}

Source: Authors, 2020 .

* McNemar test.

Table 2 - Correct practice scores of nursing students for indwelling urinary catheterization in relation to material preparation, based on observation, Sobral, CE, Brazil, 2019

\begin{tabular}{llll}
\multicolumn{1}{c}{ Questions } & $\begin{array}{c}\text { Pre-test } \\
\mathbf{n ( \% )}\end{array}$ & $\begin{array}{c}\text { Post-test } \\
\mathbf{n ( \% )}\end{array}$ & p-value* \\
1. Checked prescription with IUC & $11(37.9 \%)$ & $21(72.4 \%)$ & 0.031 \\
2. Sanitized hands & $16(55.2 \%)$ & $29(100 \%)$ & $<0.001$ \\
3. Identified and evaluated the user & $26(89.7 \%)$ & $29(100 \%)$ & 0.250 \\
4. Identified himself or herself to patient & $27(93.1 \%)$ & $28(96.6 \%)$ & 1.000 \\
5. Provides guidelines to patient about & $27(93.1 \%)$ & $28(96.6 \%)$ & 1.000 \\
the procedure & $28(96.6 \%)$ & $28(96.6 \%)$ & 1.000 \\
6. Obtained patient consent & $19(65.5 \%)$ & $29(100 \%)$ & 0.002 \\
7. Prepared the necessary material & $28(96.6 \%)$ & $28(96.6 \%)$ & 1.000 \\
8. Ensured privacy & & & \\
\hline
\end{tabular}

Source: Authors, 2020

* McNemar test. 
Table 3 - Correct practice scores of nursing students for indwelling urinary catheterization in relation to procedure execution, based on observation, Sobral, CE, Brazil, 2019

\begin{tabular}{|c|c|c|c|}
\hline Questions & $\begin{array}{l}\text { Pre-test } \\
\text { n(\%) }\end{array}$ & $\begin{array}{l}\text { Post-test } \\
\text { n(\%) }\end{array}$ & p-value* \\
\hline 1. Positioned the patient & $6(20.7 \%)$ & $12(41.4 \%)$ & 0.146 \\
\hline 2. Put on procedure gloves & $2(6.9 \%)$ & $27(93.1 \%)$ & $<0.001$ \\
\hline 3. Performed intimate hygiene & $22(75.9 \%)$ & $24(82.8 \%)$ & 0.754 \\
\hline 4. Took off the gloves & $22(75.9 \%)$ & $22(75.9 \%)$ & 1 \\
\hline 5. Sanitized hands & $23(79.3 \%)$ & $23(79.3 \%)$ & 1 \\
\hline 6. Placed the tray next to the patient & $13(44.8 \%)$ & $24(82.8 \%)$ & 0.019 \\
\hline 7. Correctly opened catheterization material and other materials & $16(55.2 \%)$ & $29(100 \%)$ & $<0.001$ \\
\hline 8. Placed the catheter inside the tray & $10(34.5 \%)$ & $27(93.1 \%)$ & $<0.001$ \\
\hline 9. Placed antiseptic in round tub or gauze & $17(58.6 \%)$ & $27(93.1 \%)$ & 0.013 \\
\hline 10. Put on sterile gloves & $19(65.5 \%)$ & $29(100 \%)$ & 0.002 \\
\hline 11. Tested the catheter balloon & $21(72.4 \%)$ & $29(100 \%)$ & 0.008 \\
\hline 12. Connected the catheter to the collecting bag & $17(58.6 \%)$ & $29(100 \%)$ & $<0.001$ \\
\hline 13. Prepared anesthetic/lubricant gel. & $14(48.3 \%)$ & $27(93.1 \%)$ & 0.001 \\
\hline 14. Prepared ampoule of distilled water & $20(69 \%)$ & $26(89.7 \%)$ & 0.109 \\
\hline 15. Performed antisepsis & $21(72.4 \%)$ & $26(89.7 \%)$ & 0.180 \\
\hline 16. Correctly disposed of used gauze & $11(37.9 \%)$ & $28(96.6 \%)$ & $<0.001$ \\
\hline 17. Placed fenestrated drape & $22(75.9 \%)$ & $27(93.1 \%)$ & 0.180 \\
\hline 18. Replaced possibly contaminated material & $11(37.9 \%)$ & $20(69 \%)$ & 0.049 \\
\hline 19. Injected anesthetic gel/lubricant into the patient's urethral meatus & $18(62.1 \%)$ & $26(89.7 \%)$ & 0.039 \\
\hline $\begin{array}{l}\text { 20. Inserted catheter into urinary meatus after positioning the } \\
\text { penis correctly }\end{array}$ & $15(51.7 \%)$ & $22(75.9 \%)$ & 0.118 \\
\hline 21. Inflated balloon with distilled water & $15(51.7 \%)$ & $29(100 \%)$ & $<0.001$ \\
\hline 22. Positioned non-dominant hand correctly during the procedure & $20(69 \%)$ & $29(100 \%)$ & 0.004 \\
\hline 23. Gently pulled the probe until it reached the bladder neck & $20(69 \%)$ & $29(100 \%)$ & 0.004 \\
\hline 24. Did not contaminate material during the procedure & $19(65.5 \%)$ & $26(89.7 \%)$ & 0.065 \\
\hline 25. Removed the fenestrated drape & $12(41.4 \%)$ & $15(51.7 \%)$ & 0.664 \\
\hline 26. Fastened the catheter to the supra-pubic region & $18(62.1 \%)$ & $26(89.7 \%)$ & 0.039 \\
\hline 27. Positioned the collecting bag correctly & 21 (72.4\%) & 28 (96.6\%) & 0.039 \\
\hline
\end{tabular}


Regarding care after catheter insertion, improvements were observed in the practice in relation to guidelines for catheter care and hand hygiene ( $p>0.001$ ) (Table 4).
In addition to the significant increase in the medians of correct theory and practice scores, as observed in the tables above, a significant increase of correct scores was observed in 22 of the 36 observed skill items.

Table 4 - Correct practice scores of nursing students for indwelling urinary catheterization in relation to care after catheter insertion, based on observation, Sobral, CE, Brazil, 2019

\begin{tabular}{lccc}
\multicolumn{1}{c}{ Questions } & $\begin{array}{c}\text { Pre-test } \\
\mathbf{n ( \% )}\end{array}$ & $\begin{array}{c}\text { Post-test } \\
\mathbf{n ( \% )}\end{array}$ & p-value* \\
\hline 1. Provided catheter care guidelines & $23(79.3 \%)$ & $29(100 \%)$ & 0.031 \\
2. Ensured the patient was comfortable, disposed of material & $19(65.5 \%)$ & $23(79.3 \%)$ & 0.424 \\
3. Sanitized hands & $8(27.6 \%)$ & $23(79.3 \%)$ & $<0.001$ \\
4. Recorded the procedure & $12(41.4 \%)$ & $20(69 \%)$ & 0.096 \\
\hline
\end{tabular}

Source: Authors, 2020.

* McNemar test.

\section{DISCUSSION}

Safe and effective nursing practice depends on knowledge and skills, which must be acquired and improved during the education and training period. According to a mixed-method study conducted in India in 2017 that reviewed academic curricula in 78 educational institutions, patient safety was not included in all the planned content of any of the reviewed curricula ${ }^{(13)}$.

Student training involves a complex system with numerous variables that cover different teaching practices, diversity of content, permanent reflection on the information of reality, and problematization of the work method. The creators of teaching policies stress the need to re-evaluate curricula, incorporate patient safety, and develop specific competencies ${ }^{(14)}$.

Further studies should be conducted on innovative teaching methodologies that stimulate the understanding of theory and practice content and contribute to the development of knowledge and appropriate practices in health care. Moreover, enhancing the training of nursing students with these methodologies on subjects involving the pillars of patient safety will enable a better experience in the curricular stages and reduce adverse events ${ }^{(15)}$.

Therefore, research on nursing procedures should be conducted to consolidate theory and practice knowledge for effective and quality nursing care.

In this regard, students must seek to build their own knowledge. Several education-based technologies that promote learning are available. Educational technology does not merely involve the use of means but provides information for students and professors to construct and reconstruct knowledge. The arc of Maguerez used in this study is one of these technologies since it promotes problem-based teaching and learning ${ }^{(16)}$.

Another quasi-experimental single-group study conducted in Minas Gerais with 95 nurses to teach pressure injury based on the methodological framework of Charles Maguerez's arc showed that the educational intervention improved the knowledge of the nurses and the problem-based approach favored applicability of the learned concepts ${ }^{(17)}$.

Regarding the theory test of the students, the questions that showed significant improvements of correct scores were handling of materials during the procedure, positioning of the penis for catheter insertion, and completion of the IUC.

According to a similar study conducted with students in the seventh and eighth periods of a nursing course in Minas Gerais, Brazil, the knowledge of IUC improved among students who were trained using active methodologies. Furthermore, the results consolidate the findings of this study since higher averages for material handling, with 89.70\% of correct answers, and completion of the procedure, with $65.5 \%$ of correct answers, were also observed(6).

Performing the technique in the correct sequence is one of the most important aspects of the procedure. However, students find it difficult to improve their skills in this technique during internships ${ }^{(18)}$. In the present study, the methodology used obtained positive results for the item on the correct sequence of IUC, with significant difference and improvements in the post-test. 
According to a study conducted in the United States with 13 students, the limitations to understanding the correct sequence of the procedure are divergence of information in the literature and the fact that some professors are updated on this practice and others are not. The study further reveals that information in student education and evaluations should be standardized ${ }^{(19)}$.

In the analysis of practice knowledge regarding preparation of the material, a significant improvement was observed in the items checking prescription, hand hygiene, and preparation of the necessary material.

Checking the prescription is a relevant assignment of nurses since it supports performance of the procedure and confirms that the patient will benefit from the use of the catheter; however, limitations are observed regarding this nursing practice in studies ${ }^{(6,18-19)}$ in terms of knowledge and skills of students and nursing professionals regarding IUC.

Hand hygiene is a critical step for the prevention of infections and this item obtained positive averages in terms of knowledge of this practice among the students. In contrast, in a study conducted in Maranhão, Brazil, on IUC, the nurses did not performed hand hygiene in $57 \%$ of the procedures ${ }^{(19)}$.

An observational study conducted in an adult intensive care unit in Minas Gerais, Brazil, showed an overall adherence rate to hand hygiene before and after handling the bladder catheter of $5.8 \%$ and $33.5 \%$, respectively $(p=0.002)^{(20)}$.

The item about preparation of materials asked which hospital elements are required to carry out the procedure, to which most students chose the correct alternative in the post-test. Another study also obtained satisfactory results, with $89.70 \%$ correct answers regarding the students'knowledge of the necessary materials ${ }^{(6)}$.

The results of the questions on execution of the procedure obtained important statistical differences before and after the adopted educational methodology, especially for the items putting on procedure gloves; placing tray close to the patient; correctly opening the catheterization material and other materials; placing catheter inside the tray; placing antiseptic in the round tub or gauze; putting on sterile gloves; testing the catheter balloon; connecting the catheter to the collecting bag; preparing the lubricating gel; anesthetic in the urethral meatus; inflating the balloon; positioning of the hands during the procedure and pulling the probe.

According to a clinical study conducted in China with 26 nursing students in the control and intervention groups to evaluate the effect of a simulation-based educational methodology on improving understanding and skills for IUC revealed no significant difference in theory knowledge; however, the results showed significant improvements in clinical skills in the group with simulation-based learning ${ }^{(21)}$.

A study conducted in Rio Grande do Sul revealed deficiencies in the knowledge and ability of nursing students, especially from the first semesters, in semiology practices, including IUC, and further showed that active learning methodologies provide teaching-learning process situations that continuously manage the construction, deconstruction, and reconstruction of knowledge ${ }^{(22)}$.

In general, significant improvements were observed among the students in the skills needed to perform the procedure. A randomized study conducted in South Korea showed that an active methodology is useful for teaching clinical skills to nursing students. In addition, it was effective in improving motivation and confidence during the practice of IUC(23).

With regard to post-IUC care, the questions with the best differences between pre-and post-test were related to the patient guidelines on catheter care and hand hygiene after the procedure.

According to a study conducted in Maranhão, Brazil, with nursing professionals on IUC, in 53 (95\%) procedures, the nurses did not provide patient guidelines appropriately although this task is among the duties of nurses, as provided for in the Code of Ethics for Nurses.

An integrative literature review carried out with twelve articles on effective measures to avoid UTI reinforced patient health education on catheter-related care as a strategy to reduce infections and reduce hospital costs ${ }^{(6)}$. Therefore, this topic must be more extensively addressed when teaching nursing students about IUC to ensure they understand the risks and benefits of its use, according to the literature, for improving the evidence-based practice.

Nursing records are the legal support of professional nurses and ensure the continuity of nursing care provided to patients.

IUC is an invasive procedure that requires adequate training for correct execution and, although many consider it a simple process, it is associated with several complications to patients.

In the academy, nursing students often exhibit stress and anxiety when faced with this procedure due to the sterile technique and the correct sequence of the steps required for the procedure( ${ }^{(7)}$.

Thus, teaching and learning must ensure a participatory and shared experience that allows students to practice the knowledge acquired. The problem-based methodology with clinical cases adopted herein and mediated by the arc of Maguerez contributed with discussions on the stages of 
indwelling urinary catheterization and the level of knowledge and skills of nursing students.

In addition, the results of this study may serve as a basis for improving the application of dynamic and effective teaching methodologies in the training of critical nursing professionals with practical skills supported by scientific evidence.

The limitations of the study include the short time interval between the educational intervention and the post-test and the absence of a true control group since it was represented by the participant himself. Moreover, it was not possible to verify how the variables analyzed would behave in longer intervals and in another group. Because it is the first contact with the practice of IUC, it can also be inferred that the data obtained are the effects of a common educational intervention.

\section{CONCLUSION}

Based on the findings of this study, it can be inferred that the knowledge and skills of the students improved after the educational intervention.

With regard to knowledge, the median of correct scores increased from 7 to 9 , with significance $(p>0.001)$. A separate analysis of each question revealed that, of the 12 items, four (checking the prescription, performing hand sanitization, and preparing the material before starting the procedure) showed an increase in correct scores with statistical significance.

In terms of skills, the median of correct scores increased from 28 to 36, with statistical significance ( $p>0.001$ ). A separate analysis of each item revealed that, of the 39 items, 22 showed improvements, including prior hand hygiene, ensuring privacy, positioning the user, correct opening of catheterization material and other materials, performing antisepsis, introducing the catheter into the urinary meatus after positioning the penis correctly, and recording the procedure in the patient's medical record.

Further studies should be conducted with designs that produce strong evidence (randomized controlled trials and meta-analyses) related to the theory and practice knowledge of IUC. Moreover, future studies can compare the use of the Maguerez arc with other teaching strategies and investigate longer time intervals between intervention and post-test.

\section{REFERENCES}

1. Cavalcante TMC, Braquehais AR, Bezerra PARG. Sonda vesical de demora: perfil epidemiológico da infecção urinária no centro de terapia intensiva. RETEP - Rev Tendên Enferm Profis. 2017 [cited 2020 Jan 12];9(2):2164-9. Available from: http://www.coren-ce.org.br/wp-content/uploads/2019/02/SONDA-VESICALDE-DEMORA-PERFIL-EPIDEMIOL\%C3\%93GICO-DA-INFEC\%C3\%87\%C3\%830URIN\%C3\%81RIA.pdf
2. Carrouget J, Legeay C, Poirier A, Azzouzi AR, Zahar JR, Bigot P. Enquête de prévalence sur le sondage vésical dans un centre hospitalo-universitaire. Progr Urol. 2017;27(5):305-11. doi: https://doi.org/10.1016/j.purol.2017.03.006

3. Chaves NMO, Moraes CLK. Controle de infecção em cateterismo vesical de demora em unidade de terapia intensiva. REnferm Cent 0 Min. 2015 [cited 2020 Jan 20];5(2):16507. Available from: http://seer.ufsj.edu.br/index.php/recom/article/view/773/867

4. Silva MFB, Santana JS, Silva CCFL. Atuação do enfermeiro na prevenção da infecção do trato urinário em pacientes com sonda vesical de demora. Enf Rev. 2019 [cited 2020 Jan 06];22(2). Available from: http://periodicos.pucminas.br/index.php/ enfermagemrevista/article/view/21081

5. Amaral DM. Postoperative vulvectomy and gallbladder catheterism: integrative review. Rev Enferm UFPE online, 2017 [cited 2019 Dec 18];11(10):3948-57. Available from: https://periodicos.ufpe.br/revistas/revistaenfermagem/article/view/14283

6. Lopes AM, Souza CC, Teixeira A0. Nursing students theoretical knowledge about urinary catheterization delay. Rev Enferm Cent 0 Min. 2018 [cited 2019 Dec 18];8e2869. Available from: http://www.seer.ufsj.edu.br/index.php/recom/ article/view/2869/2003

7. Orosco SS, Silva CG, Almeida TK. Conhecimento dos acadêmicos de enfermagem sobre a técnica em cateterismo vesical. Collog Vitae. 2019;11(3):62-71. doi: https:// doi.org/10.5747/cv.2019.v11.n3.v271

8. Cohen A, Nottingham C, Packiam V, Jaskowiak N, Gundeti M. Attitudes and knowledge of urethral catheters: a targeted educational intervention. BJU Int. 2016;118(4):654-9. doi: https://doi.org/10.1111/bju.13506

9. Azevedo SB, Pacheco VA, Santos EA. Active methodologies in higher education: teacher perception in a private Federal District institution. Rev Docência Ens Sup. 2019 [cited 2020 Mar 20];9:e002573. Available from: https://periodicos.ufmg. br/index.php/rdes/article/view/2573

10. Esperidião E, Souza A, Caixeta CC, Pinho ES, Nunes, FC. Arco de Maguerez: estratégia de metodologia ativa para coleta de dados. Atas CIAIQ: Invest Qualit Saúde. 2017 [cited 2020 Mar 20];2:825-34. Available from: https://proceedings.ciaiq.org/ index.php/ciaiq2017/article/view/1279/1239

11. Clapis MJ, Marques EA, Corrêa AK, Souza MCBM, Borda KP. Problematization methodology in primary healthcare teaching. Rev Bras Enf. 2018;71:1671-7. doi: https://doi.org/10.1590/0034-7167-2017-0157

12. Balduino LSC. Validação de instrumentos para avaliação do conhecimento e da habilidade acerca da sondagem vesical de demora [dissertação]. Natal (RN): Universidade Federal do Rio Grande do Norte; 2013 [cited 2020 Sep 10]. Available from: https://repositorio.ufrn.br/bitstream/123456789/14794/1/LiviaSCB_DISSERT.pdf

13. Lahariya C, GuptaS, Kumar G, De Graeve H, Parkash I, Das JK. Patient safety in graduate curricula and training needs of health workforce in India: a mixed-methods study. Indian JPublic Health. 2020;64(3):277-84.doi:https://doi.org/10.4103/ijph.IJPH_482_19

14. Bohomol E. Patient safety education of the graduation in Nursing from the teaching perspective. Esc Anna Nery. 2019;23(2):e20180364. doi: https://doi. org/10.1590/2177-9465-ean-2018-0364

15. Gomes ATL, Salvador PTCO, Goulart CF, Cecilio SG, Bethony MFG. Innovative methodologies to teach patient safety in undergraduate nursing: scoping review. Aquichan. 2020;20(1):e2018. doi: https://doi.org/10.5294/aqui.2020.20.1.8

16. Leal PM, Amante LN, Girondi JBR, Nascimento ERP, Magalhães ALP. Building solutions for the safety of the patient with heart disease using warfarin: a qualitative study. Texto Contexto Enferm. 2020;29:e20180002. doi: https://doi. org/10.1590/1980-265X-TCE-2018-0002

17. Campoi ALM, Engel RH, Stacciarini TSG, Cordeiro ALPC, Melo AF, Rezende MP. Permanent education for good practices in the prevention of pressure injury: almost-experiment. Rev Bras Enferm. 2019;72(6):1646-52. doi: https://doi. org/10.1590/0034-7167-2018-0778 
18. Gonzalez L, Sole ML. Urinary catheterization skills: one simulated checkoff is not enough: one simulated checkoffis not enough. Clin Simul Nurs. 2014;10(9):45560. doi: https://doi.org/10.1016/j.ecns.2014.07.002

19. Lee NJ, Chae SM, Kim H, Lee JH, Min HJ, Park DE. Resultados de aprendizagem por vídeo baseados em dispositivos móveis no ensino de habilidades de enfermagem clínica: um estudo controlado randomizado. Comput Inform Nurs. 2016;34(1):816. doi: https://doi.org/10.1097/CIN.0000000000000183

20. Mota EC, Oliveira AC. Prevention of catheter-associated urinary tract infection: what is the gap in clinical practice? Texto Contexto Enferm. 2019;28:e20180050. doi: https://doi.org/10.1590/1980-265X-TCE-2018-0050

\section{- Authorship contributions:}

Conceptualization: Jonatan Deyson do Nascimento de Sousa.

Formal analysis: Livia Moreira Barros.

Methodology: Jonatan Deyson do Nascimento de

Sousa, Cristina da Silva Fernandes, Maria Aline Moreira

Ximenes, Lívia Moreira Barros.

Project administration: Livia Moreira Barros.

Writing - original draft: Jonatan Deyson do Nascimento de Sousa, Cristina da Silva Fernandes, Maria Aline

Moreira Ximenes.

Writing - review and editing: Joselany Áfio Caetano,

Nelson Miguel Galindo Neto, Lívia Moreira Barros.

\section{- Corresponding author:}

Cristina da Silva Fernandes

E-mail: cristina.sednanref@gmail.com
21. Kim Y, Choi N, Bang H. The development and effects of a simulation-based practicum education program on urinary catheterization care for women. Int J Adv Sci Technol. 2018;113:1-10. doi: https://doi.org/10.14257/ijast.2018.113.01

22. MeloGSM, Tibúŕcio MP, Freitas CCS, Vasconcelos QLDAQ, Costa IKF,Torres IGV.Semiotics and semiology of Nursing: evaluation of undergraduatestudent'snowledge on procedures. Rev BrasEnferm. 2017;70(2):249-56. doi:https://doi.org/10.1590/0034-7167-2016-0417

23. Barros LAA, Paiva SS, Gonçalves Filho A, Sousa SMA. Risk nursing diagnostics for adverse events in bladder catheterization installation delay. Rev Enferm UFPE on line. 2016 [cited 2020 Sep 10];10(9):3302-12. Available from: https://periodicos. ufpe.br/revistas/revistaenfermagem/article/view/11410

\section{Associate editor:}

Graziella Badin Aliti

\section{Editor-in-chief:}

Received: 04.23.2020

Maria da Graça Oliveira Crossetti 